\title{
Effects of nitrogen supplementation on Saccharomyces cerevisiae JP14 fermentation for mead production
}

Eduardo Luís Menezes de ALMEIDA, Gustavo MOREIRA E SILVA², Igor de Albuquerque VASSALLI ${ }^{2}$, Mayara Salgado SILVA ${ }^{3}$, Weyder Cristiano Santana ${ }^{4}$, Paulo Henrique Alves da SILVA ${ }^{1}$, Monique Renon ELLER ${ }^{1 *}$

\begin{abstract}
Honey must supplementation is necessary for mead production due to the deficiency in nitrogen materials in this feedstock, despite its high fermentative sugar content. The nitrogen limitation can halt or slow fermentation and lead to the production of unpleasant sensorial compounds, such as sulfur derivatives. The yeast JP14, a Saccharomyces cerevisiae isolated from Jataí bee's pollen, was inoculated in $25^{\circ}$ Brix honey must with - 0 (control); 0,$3 ; 0,7$ and $1,0 \mathrm{~g} \cdot \mathrm{L}^{-1}$ - of di-ammonium phosphate (DAP) and ammonium sulfate (AS). The addition of both supplements resulted in increased cell viability in the first 5 days of fermentation at $20^{\circ} \mathrm{C}$, but did not affect the final acidity of the produced meads. Supplementation also leads to increased sugar consumption, and sugar conversion into ethanol increased as nitrogen supplementation increased, especially with DAP. This indicates that these compounds also regulate yeast metabolic pathways. Supplementary nitrogen acts both in protein anabolism and the gene expression of glycolytic and fermentative pathway components, favoring, in this case, sugar conversion into ethanol. This is the first work describing how different DAP and AS concentrations influences mead production and showing the comparison between these two supplements.
\end{abstract}

Keywords: yeasts; beverages; ammonium; additives.

Practical Application: Optimization of mead production.

\section{Introduction}

In nature, yeasts are capable of using a wide range of compounds containing nitrogen. Some of these compounds are metabolized more efficiently and optimize growth and the metabolic activity, Barbosa et al. (2012). During the fermentative process, nitrogen limitation can halt or slow fermentation, besides stimulating the production of unpleasant sensorial compounds, such as sulfur derivatives, Mendes-Ferreira et al. (2004).

Mead is considered the oldest known alcoholic beverage Aquarone et al. (1983). However, mead production is not standardized and techniques and ingredients from winemaking are often used. However, using different feedstocks requires different upstream operations, including honey must supplementation, which is a feedstock deficient in nitrogen sources.

In search for new yeasts for mead fermentation, our research group isolated and identified yeasts from different apicultural sources and selected them for their fermentative capacity. Among the isolated yeasts, the strain JP14, identified as a Saccharomyces cerevisiae, stands out for its great potential to produce mead and other beverages. However, fermentative process scheduling led to productivity problems that could affect the industrial scale application viability.

Must supplementation with nitrogen sources reduces the harmful effects from low nutrient availability in feedstock.
Ammonium sulfate (AS) and di-ammonium phosphate (DAP) are efficient alternatives for fermentation in sugarcane must, Vidal et al. (2013), grape must, Childs et al. (2015) and apple, Kelkar \& Dolan (2012). Mendes-Ferreira et al. (2010) evaluated DAP supplementation together with acids, but, to the present date, no works were found with only DAP addition compared to AS, or the determination of its respective optimal points, as supplements for honey must. The use of these sources must be evaluated specifically for each must and the fermentation agent utilized, in order to obtain the ideal type and concentration of these agents for each beverage to be produced. Therefore, this work aims to study ammonium sulfate (AS) and di-ammonium phosphate (DAP) as sources for honey-based must for mead production by yeast JP14.

\section{Materials and methods}

\subsection{Pre-inoculum preparation and yeast stock maintenance}

The yeast JP14 was obtained from the microorganism bank of the Laboratory of Biochemical and Fermentative Processes of the Department of Food Technology of the Universidade Federal de Viçosa. The yeast was propagated in YEPG medium $\left[0,5 \%(\mathrm{w} / \mathrm{v})\right.$ yeast extract - KASVI ${ }^{\circledR}, 1 \%(\mathrm{w} / \mathrm{v})$ peptone - IMEDIA ${ }^{\circledR}$ e $2 \%(w / v)$ glucose - $\left.\mathrm{NEON}^{\circledR}\right]$ at $30^{\circ} \mathrm{C}$ until $10^{7} \mathrm{cel} \cdot \mathrm{mL}^{-1}$ count. 
The pre-inoculum was centrifuged at $3370 \times \mathrm{g}$ for $10 \mathrm{~min}$ and resuspended in $50 \mathrm{~mL}$ of must with $5 \%(\mathrm{w} / \mathrm{v})$ honey containing $0.015 \%(\mathrm{w} / \mathrm{v})$ sodium metabisulfite (Indupropil ${ }^{\circledR}$ ). After $12 \mathrm{~h}$ of adaptation, at $30{ }^{\circ} \mathrm{C}$ without agitation, it was transferred to Erlenmeyers with $25^{\circ}$ Brix honey must. The pre-inoculum was incubated for $24 \mathrm{~h}$ at $30{ }^{\circ} \mathrm{C}$ and $150 \mathrm{rpm}$ until $10^{8} \mathrm{cel} \cdot \mathrm{mL}^{-1}$ count, utilized for must inoculation (item 2.2.) at $10^{6} \mathrm{cel} \cdot \mathrm{mL}^{-1}$. Silva (2016)

The yeast JP14 was maintained at $-15^{\circ} \mathrm{C}$ in YEPG medium containing $20 \%$ (w/v) glycerol until the moment of its use.

\subsection{Must preparation and inoculation}

Six different musts were prepared, besides one control, in triplicate, which totaled 21 fermentation vessels. Three musts were supplemented with $0.3 ; 0.7$ and $1.0 \mathrm{~g} \cdot \mathrm{L}^{-1}$ of di-ammonium phosphate (DAP), while the other three received ammonium sulfate (AS) at the same concentrations. The control treatment corresponded to the must without any nitrogen supplementary sources.

In must preparation, honey was diluted in sterile mineral water until $25^{\circ}$ Brix and added of $0.015 \%(w / v)$ of sodium metabisulfite. Next, they were supplemented with the nitrogen sources, as mentioned above. The musts were pasteurized at $65^{\circ} \mathrm{C}$ for $30 \mathrm{~min}$, immediately cooled, and then inoculated with the yeast JP14 at approximately $10^{6} \mathrm{cel} \cdot \mathrm{mL}^{-1}$. The system was homogenized and assembled using airlocks to allow gas exhaust and sampling, so as to prevent oxygen entrance in the system. The inoculated musts were maintained at $20^{\circ} \mathrm{C}$ for fermentation.

\subsection{Monitoring of the fermentative process}

During the seven first days of fermentation (tumultuous fermentation), cell viability, total soluble solids, reducing sugar, acid content, turbidity (Optical Density - O. D., at $600 \mathrm{~nm}$ ) and free amino nitrogen (FAN) were monitored every $24 \mathrm{~h}$. After the seven first days, the analysis were carried out every seven days, until day 28 . The liquids were transferred to new flasks and cooled at $10{ }^{\circ} \mathrm{C}$ for the stabilization (maturation) of the product. In the end of $30 \mathrm{~d}$, the samples were analyzed for ethanol quantification through High Performance Liquid Chromatography (HPLC). Finally, 50\% (w/v) of the clarifying agent bentonite (Indupropil ${ }^{\circledR}$ ) was added. After $48 \mathrm{~h}$, the samples were transferred to new flasks, and the mead production process was concluded.

\subsection{Analytical methods}

The cell concentration was calculated based on viable cell counting in Neubauer Chamber using methylene blue vital dye, Pierce (1970). The content of soluble solids ( $\left.{ }^{\circ} \mathrm{Brix}\right)$ was determined with the aid of an analogic refractometer $\left(\right.$ ATC $\left.^{\circledR}\right)$. Total acidity followed the titulometric method using sodium hydroxide $0.1 \mathrm{~N}$ solution. The results were given in meq $\cdot \mathrm{L}^{-1}$. L'Organisation Internationale de la Vigne et du Vin (2015).

Reducing sugar content was determined through the 3.5-dinitrosalicilic acid (DNS) method: One $100 \mu \mathrm{L}$ aliquot of the studied samples was transferred to microtubes containing
$300 \mu \mathrm{L}$ of DNS reagent, Sumner (1921); Vasconcelos et al. (2013). The mixture was agitated and incubated in water bath at $90{ }^{\circ} \mathrm{C}$ for $10 \mathrm{~min}$. After cooling, $1.6 \mathrm{~mL}$ of distillated water were added, and the absorbance reading was conducted in a spectrophotometer at $540 \mathrm{~nm}$. Distillated water was used to replace sample aliquots for blanking. A standardized curve was generated to estimate the reducing sugars present in the samples, using glucose at concentrations between 0 and $2.0 \mathrm{~g} \cdot \mathrm{L}^{-1}$. The samples were diluted when necessary.

The ethanol concentration was determined through High Performance Liquid Chromatography. For such, aliquots of $1 \mathrm{~mL}$ of each sample were centrifuged at $2.236 \times \mathrm{g}$ and the supernatant was frozen at $-20{ }^{\circ} \mathrm{C}$ until the moment the analysis was performed. Later, the samples were injected in an Aminex ${ }^{\circledR} \mathrm{HPX}-87 \mathrm{H}$ column with sulfuric acid at $5 \mathrm{mM}$ as mobile phase $\left(\right.$ VETEC $\left.^{\circledR}\right)$ and identified by a refraction index detector. The ethanol concentrations used for the preparation of the standard curve were $3,5,10,25,50,75,100$ and $150 \mathrm{mM}$. The peak area obtained from the chromatogram was used to determine the ethanol concentration in the samples.

The free amino nitrogen (FAN) was determined by the spectrophotometric method, Abernathy et al. (2009), using dye reagent ninidrine $2 \%$ in glycol etilene/sodium acetate $(\mathrm{pH} 5,5)$ buffer and glycine to prepare a standard curve. The absorbance of each reaction was measured at $575 \mathrm{~nm}$.

\subsection{Statistical analysis}

The experiments produced in this work were arranged in a completely randomized design, with three replications. Data analysis was conducted with the aid of the ASSISTAT software system, Silva \& Azevedo (2016). An analysis of variance was carried out between the samples using the $\mathrm{F}$ test at a $5 \%$ probability level. When differences were detected, the Tukey test was conducted, at the same probability level, for the comparison between different nitrogen sources. The evaluation of the effect of different concentrations for the same supplementary source was analyzed through a regression analysis using ANOVA.

\section{Results}

The meads produced with DAP and AS showed significant differences between them and when compared to the control (Table 1). Nitrogen supplementation leads to musts with similar FAN and reducing sugar concentrations, but supplementation with DAP leads to more efficiency in sugar conversion into ethanol by the yeast. However, the increase in FAN content did not result in a significant difference in final acidity and viable cell count. Supplementations with both DAP and AS increased cell viability (Figure 1A and B) in musts until the third fermentation day, independently of the concentration, compared to control. During the rest of the fermentation process, nitrogen supplementation had little impact on cell number, which remained stable and similar until the last day for both sources and the control.

Instead, the optical density (Figure 1C and D) dropped gradually over the first week of fermentation, and then stabilized. The analyzed treatments and the control showed similar behavior, 
Table 1. Characteristics of mead produced from musts containing different nitrogen sources.

\begin{tabular}{|c|c|c|c|c|c|c|c|c|}
\hline Treatment & $\begin{array}{l}\text { Total acidity } \\
\left(\mathrm{mEq} \cdot \mathrm{L}^{-1}\right)\end{array}$ & $\begin{array}{c}\text { Viable cell } \\
\text { count } \\
\left(\text { Log cel· } \mathrm{mL}^{-1}\right)\end{array}$ & $\begin{array}{c}\text { O. D. } \\
(600 \mathrm{~nm})\end{array}$ & $\begin{array}{c}\text { FAN } \\
\left(\mathrm{mgN} \cdot \mathrm{L}^{-1}\right)\end{array}$ & ${ }^{\circ} \mathrm{BRIX}$ & $\begin{array}{l}\text { Reducing } \\
\text { sugars } \\
\left(\mathrm{g} \cdot \mathrm{L}^{-1}\right)\end{array}$ & $\begin{array}{l}\text { Ethanol } \\
(\% \mathrm{v} / \mathrm{v})\end{array}$ & $Y_{(\mathrm{P} / \mathrm{S})}$ \\
\hline Control & $41.67 \pm 1.16 \mathrm{a}$ & $5.944 \pm 0.078 \mathrm{a}$ & $0.161 \pm 0.012 \mathrm{a}$ & $33.298 \pm 4.490 b$ & $18.63 \pm 0.32 \mathrm{a}$ & $209.21 \pm 10.04 \mathrm{a}$ & $3.825 \pm 0.310 \mathrm{a}$ & $0.198 \pm 0.020 \mathrm{a}$ \\
\hline DAP $\left(1.0 \mathrm{~g} \cdot \mathrm{L}^{-1}\right)$ & $43.52 \pm 3.91 \mathrm{a}$ & $5.824 \pm 0.084 \mathrm{a}$ & $0.106 \pm 0.006 b$ & $56.300 \pm 3.741 \mathrm{a}$ & $10.10 \pm 0.10 \mathrm{c}$ & $38.17 \pm 2.09 b$ & $10.176 \pm 0.618 c$ & $0.259 \pm 0.022 c$ \\
\hline
\end{tabular}

Means followed by the same letter in the same column don't differ statistically by Tukey test $(\mathrm{P}<0.05)$.
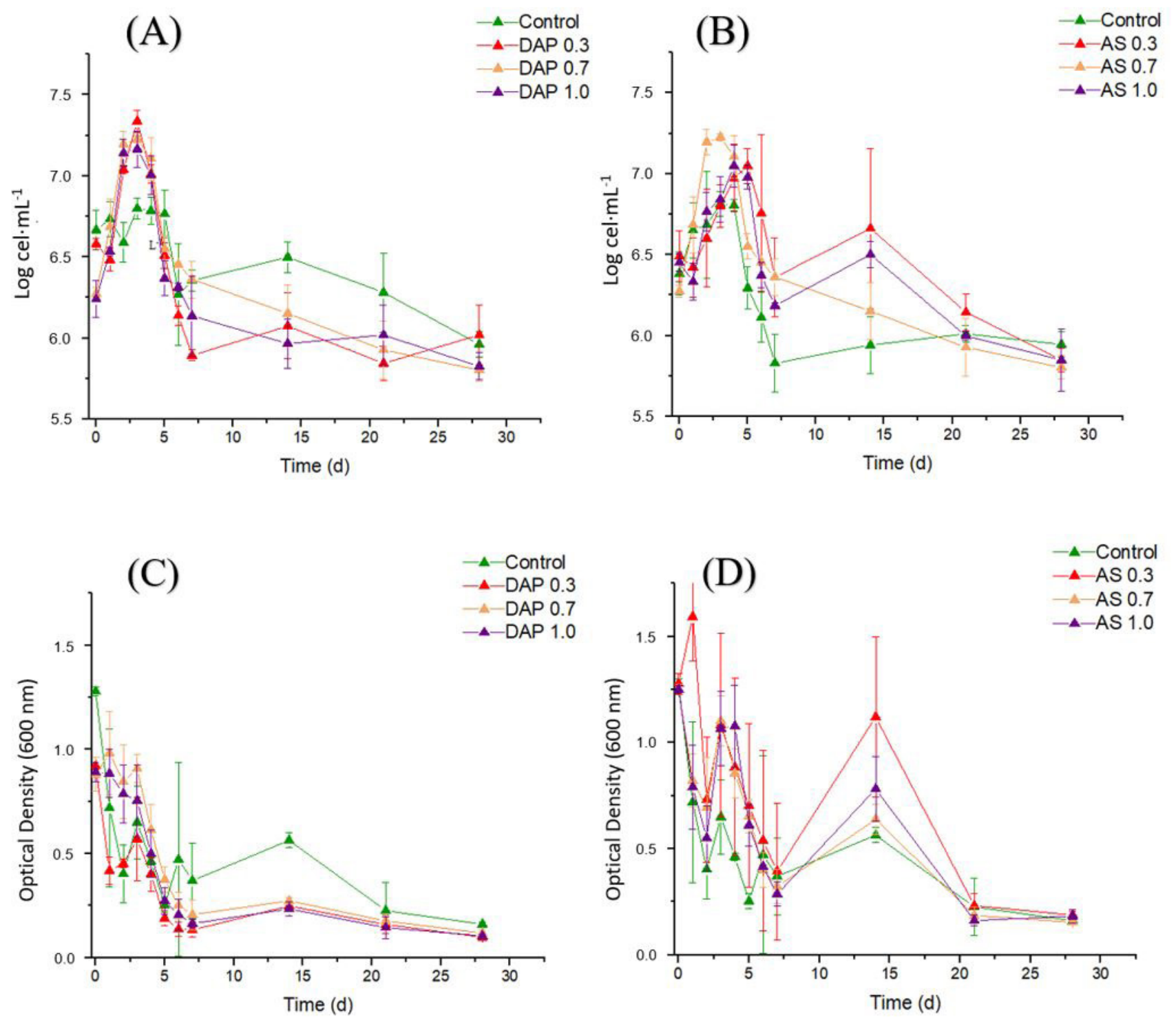

Figure 1. Cell viability of yeast JP14 [(A) and (B)] and Optical Density $(600 \mathrm{~nm})[(\mathrm{C})$ and (D)] during mead fermentation with different supplementary nitrogen sources, di-ammonium phosphate (DAP) [(A) and (C)] and ammonium sulfate (AS) [(B) and (D)]. The results are means of three replicates followed by standard deviations.

except at the end of fermentation, when the meads produced from DAP supplementation presented less turbidity than the others.

Musts showed similar total acidity (Figure 2A and B), except for those containing greater nitrogen supplement concentrations, which presented less acidity during fermentation, and became equal on the last day. The must's acidity increased gradually over the first week, and then stabilized at values between 40 and $45 \mathrm{mEq} \cdot \mathrm{L}^{-1}$.

Musts with di-ammonium phosphate (DAP) showed increased FAN (Figure 2C and D) during the first three days of fermentation, unlike the musts containing ammonium sulfate (AS), which presented decreased FAN. In all analyzed treatments, FAN 

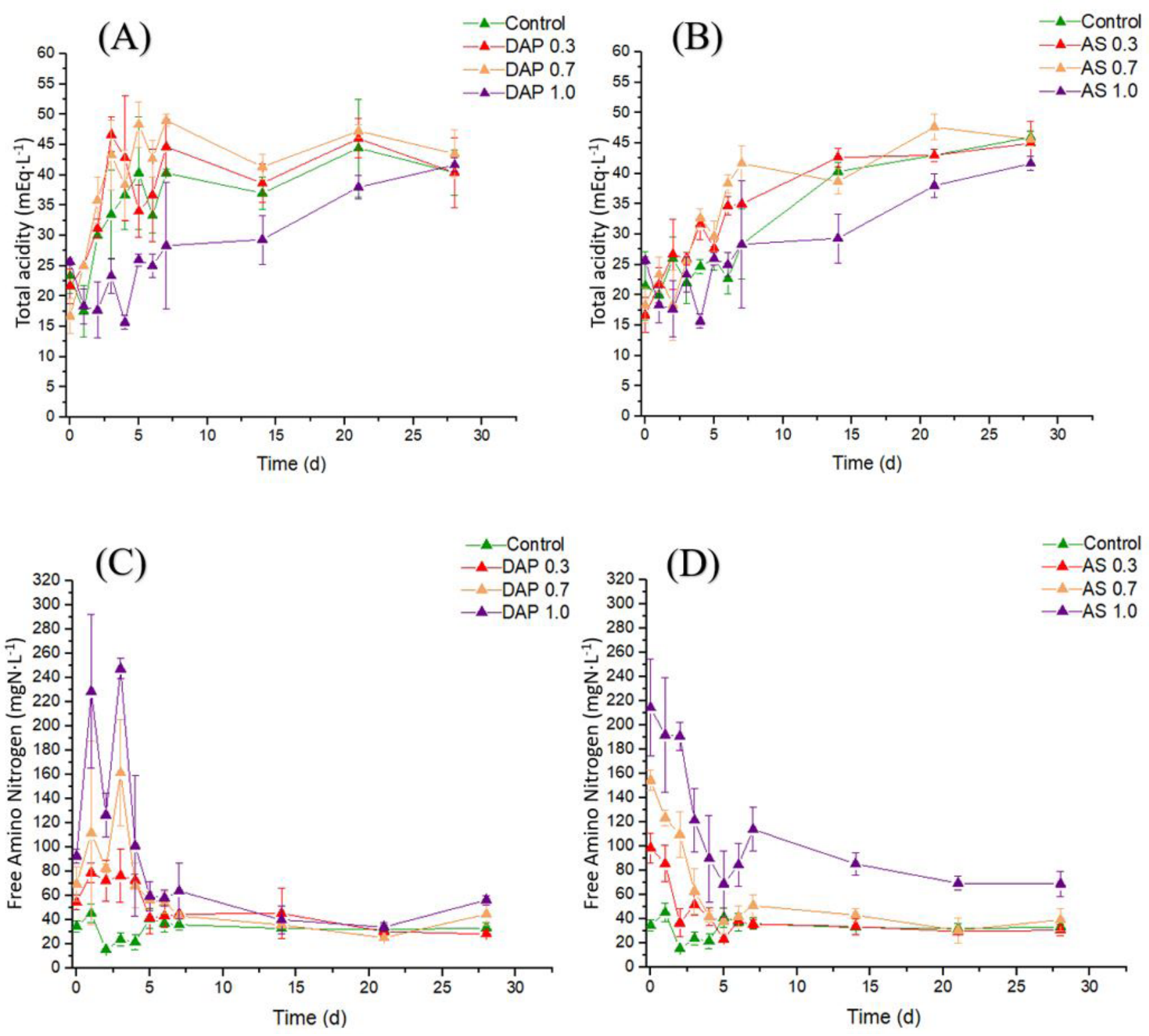

Figure 2. Total acidity (mEq.L $\left.\mathrm{L}^{-1}\right)[(\mathrm{A})$ and $(\mathrm{B})]$ and Free Amino Nitrogen $\left(\mathrm{mgN} \cdot \mathrm{L}^{-1}\right)[(\mathrm{C})$ and $(\mathrm{D})]$ during mead fermentation with different supplementary nitrogen sources, di-ammonium phosphate (DAP) [(A) and (C)] and ammonium sulfate (AS) [(B) and (D)]. The results are means of three replicates followed by standard deviations.

stabilization is observed from the seventh day, and the values are similar - close to $40 \mathrm{mgN} \cdot \mathrm{L}^{-1}$, except for musts with $1.0 \mathrm{~g} \cdot \mathrm{L}^{-1}$ of ammonium sulfate. Under such condition, the meads presented greater FAN concentration, compared to the others. Besides the greater presence of basic compounds, specially ammonia (di-ammonium phosphate and ammonium sulfate) from the supplementation used, no difference was detected in the final acidity, nor between sources, neither compared to the control (Table 1). However, musts with $1.0 \mathrm{~g} \cdot \mathrm{L}^{-1}$ of supplement presented less acidity during fermentation (Figure 2) and reached values like those of other treatments only in the end of the process.

The addition of DAP and AS has led the yeast JP14 to use more sugar, both total and reducing (Figure 3), at a concentration-dependent way, until reaching $0.7 \mathrm{~g} \cdot \mathrm{L}^{-1}$. In all cases, sugar concentration decreased until the last day of fermentation. Supplementation with 0.7 and $1.0 \mathrm{~g} \cdot \mathrm{L}^{-1}$, for both DAP and AS, led to similar yeast behavior until the end of fermentation. It is worth mentioning that the change in sugar consumption profile in musts containing lower nitrogen was observed only after the first week, when increased supplementation increased consumption.

An increased nitrogen supplementation also resulted in increased ethanol production by the yeast JP14 (Figure 4). However, sugar consumption by the yeast was similar in musts supplemented with DAP and AS. Thus, DAP supplementation provided greater conversion of these sugars into ethanol. 

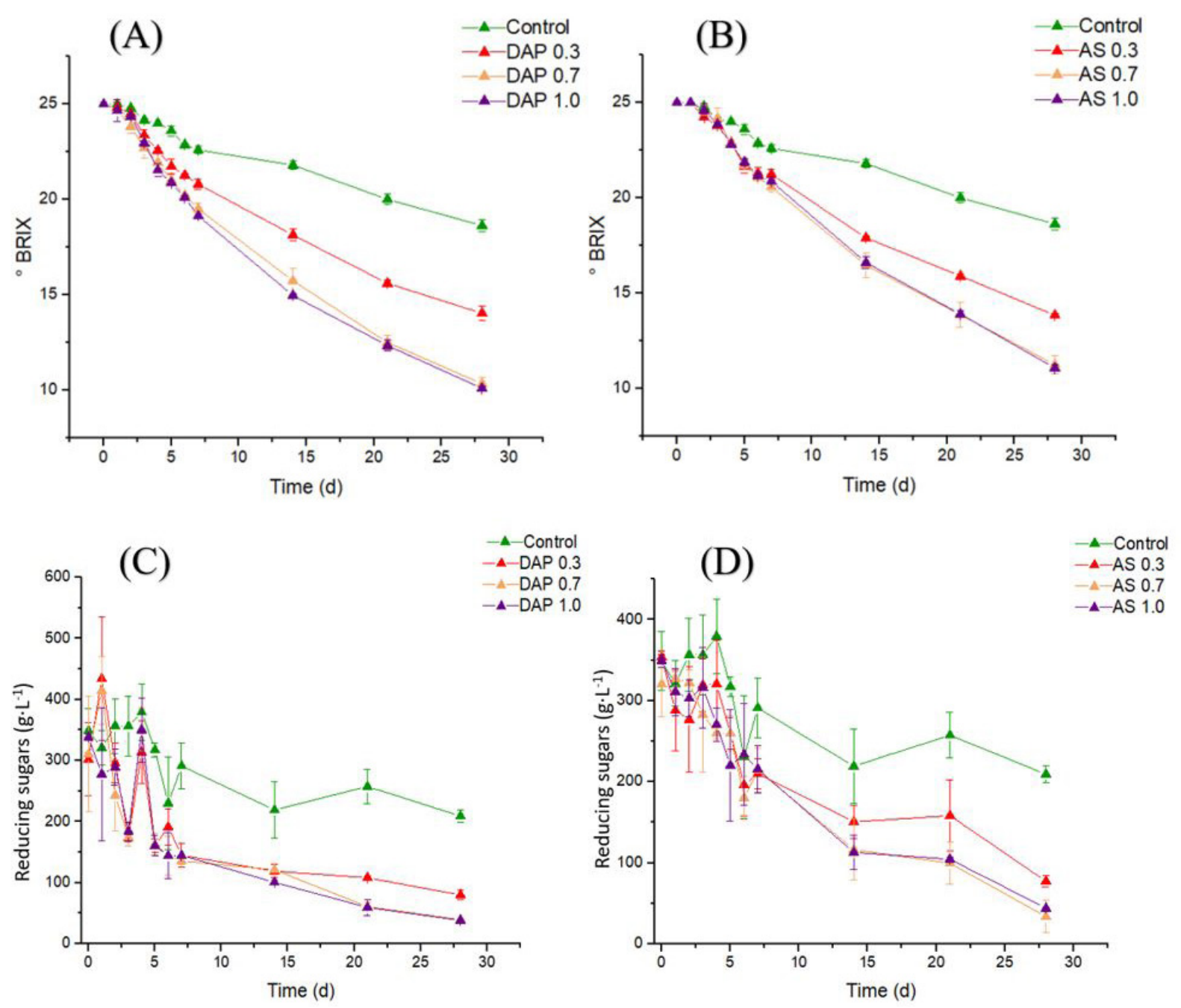

Figure 3. Soluble solid content (g.100 $\left.\mathrm{g}^{-1}{ }^{\circ} \mathrm{BRIX}\right)\left[(\mathrm{A})\right.$ and (B)] and reducing sugars $\left(\mathrm{g} \cdot \mathrm{L}^{-1}\right)[(\mathrm{C})$ and $(\mathrm{D})]$ during mead fermentation with different supplementary nitrogen sources, di-ammonium phosphate (DAP) [(A) and (C)] and ammonium sulfate (AS) [(B) and (D)]. The results are means of three replicates followed by standard deviations.
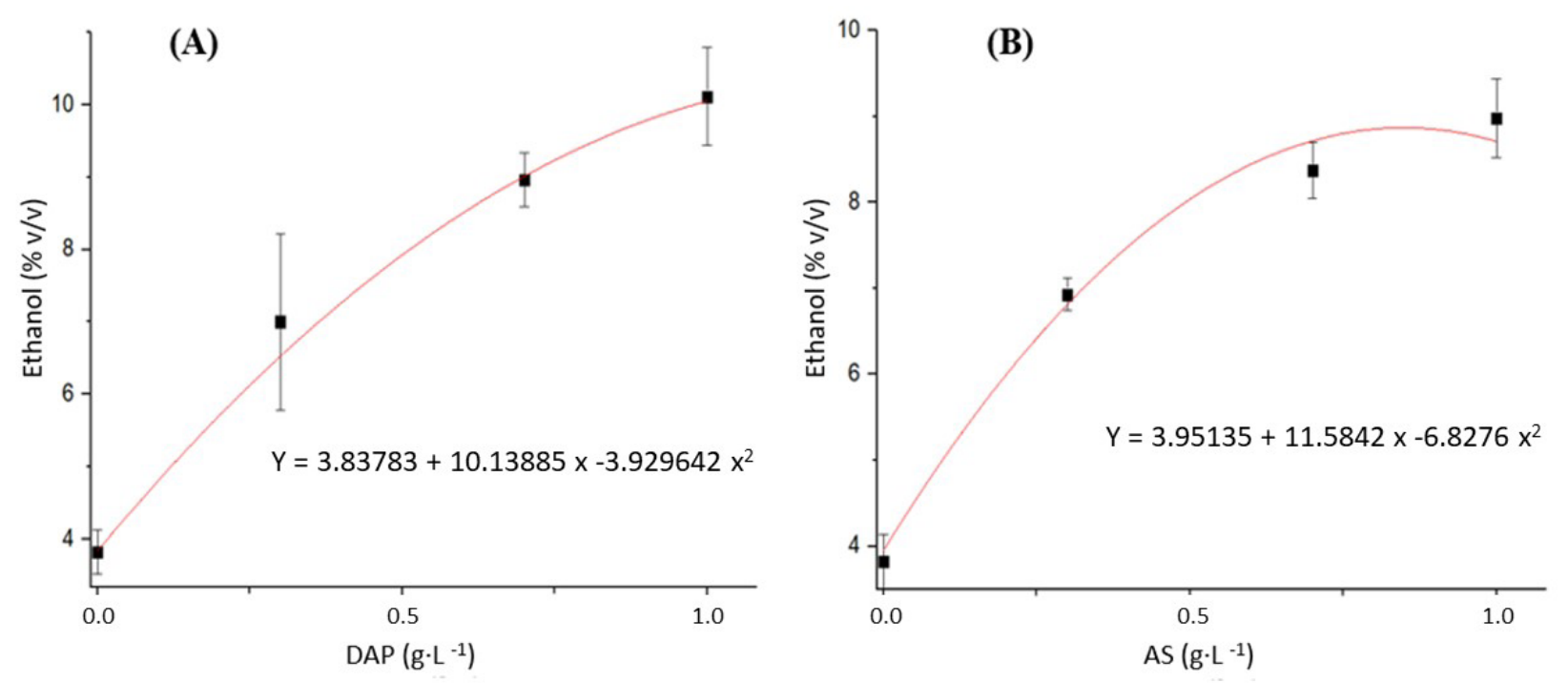

Figure 4. Relation between the nitrogen supplementation added and the ethanol production $(\mathrm{p}<0.05)$ in honey must supplemented with: (A) di-ammonium phosphate - DAP; (B) ammonium sulfate - AS. The results are the means of three replicates followed by standard deviations. 


\section{Discussion}

The Free Amino Nitrogen (FAN) quantification methodology described by Abernathy et al. 2009, initially proposed for wines and beers, showed to be also appropriated for meads. Those results help to describe and comprehend about yeast nitrogen utilization during fermentation. Besides Mendes-Ferreira et al. 2010 evaluated DAP supplementation with acids for honey must, no works were found so far, in which DAP alone or AS addition were analyzed, with the determination of their respective concentrations, as nitrogen supplementary sources for honey must.

Honey must supplementation impacted early cell growth. Bely et al. (1994) demonstrated that, for synthetic grape must [199 g.L $\mathrm{L}^{-1}$ of sugars, $3.8 \mathrm{mM}$ of FAN, 1.96 of ammoniac nitrogen and $5.85 \mathrm{mM}$ of total assimilable nitrogen], the addition of nitrogen supplementary sources did not affect $S$. cerevisiae cellular growth, even in the initial stage (tumultuous fermentation). On the other hand, Barbosa et al. (2012), Vendramini et al. (2017) and Mendes-Ferreira et al. (2009), also analyzed synthetic grape must and found increased and differentiated cellular growth stimulated by nitrogen supplementation for other S. cerevisiae strains, similarly to the findings of the present work for honey must. Therefore, the dependence of growth on the availability of nitrogen seems to be strain-dependent. For honey musts, O. D. was not proportional to yeast populational behavior, since, in the first days of fermentation, the suspended viable cell population increased, while O.D. decreased (Figure 1). It is evident that turbidity in meads, primarily in the initial stages, is related to the presence of dirt and insoluble compounds present in honey, which can reach concentrations of $0.1 \mathrm{~g} \cdot 100 \mathrm{~g}^{-1}$, Silva (2016) and continuously decant to reactor bottom throughout the fermentation.

During the final fermentation steps, beverage turbidity is mainly related to the yeast flocculation capacity during the fermentative process, which is determinant for the clarification process. Nitrogen supplementation little affected must turbidity (Figure 2), and supplementation with DAP led to meads with the least O. D. $(600 \mathrm{~nm})$ (Table 1). The observed difference, mainly for the must containing $1.0 \mathrm{~g} \cdot \mathrm{L}^{-1}$ of DAP, is due to increased ethanol content and decreased sugar content in this treatment. Sugar competes for the receptors responsible for flocculation in the membrane of yeasts, Touhami et al. (2003), acting as dispersors, Soares et al. (2004), while ethanol presence is related both with cell hydrophobicity change, Jin \& Speers (2000) and with gene expression related to the activation of the flocculation process, Claro et al. (2007), activating it, Soares (2011).

The similarity observed in the initial cellular growth for the meads produced with DAP and AS may be because both are ammoniac nitrogen sources. The use of nitrogen sources of other nature, such as amino acids, could change the behavior of cell biomass. How nitrogen is presented for cells affects its use. Amino acids as glutamic acid can be directly directed for central metabolic pathways, serving as precursors for other amino acids, or limiting the use of other amino acids in secondary pathways, like lysine, promoting higher cell growth due to a minor necessity of amino acid synthesis, and less glycerol formation due to less $\mathrm{NADH}$ formation from glucose conversion into $\alpha$-ketoglutarate.
This can also increase ethanol production, since less carbon is directed for glycerol and amino acid formation. Albers et al. (1996)

Free amino nitrogen (FAN) excess $-420 \mathrm{mg} \cdot \mathrm{L}^{-1}-$ is not related with less cell viability. In other words, the addition of nitrogen supplementation does not reduce yeast population, contrary to nitrogen starvation conditions, but may decrease sugar consumption by the cells, consequently slowing or even halting fermentation and led to the generation of undesirable aromatic compounds. Tesnière et al. (2015)

Must supplementation with DAP increased the FAN in the honey musts, which is related to increased production of nitrogen compounds by the cell, added to the activity of cell proteases on proteins present in honey, which could be present at values close to $0.5 \%(\mathrm{w} / \mathrm{w})$ Komatsu et al. (2002). This amount is considered low for yeast physiological needs. Tesnière et al. (2015).

The acidity of the produced meads were similar to those found by Mendes-Ferreira et al., 2010, (between 40 and 102,6 mEq. $\mathrm{L}^{-1}$ ) and is consistent with the Brazilian mead legislation, which requires less than $130 \mathrm{mEq} \cdot \mathrm{L}^{-1}$, Brasil (2012). High acidity could indicate the presence of contaminants in the beverages, including acetic acid bacteria. Acetic acid bacteria are strictly aerobic and occur mostly in sugary, alcoholic and acidic niches, such as must for fermented beverages, and its main product - acetic acid can increase total acidity, Mamlouk \& Gullo (2013). Therefore, the low acidity of the meads indicates the absence of these contaminants. Ribereau-Gayon et al. (2006)

For all musts that received nitrogen supplementation, yeast consumed more sugar and produced more ethanol during fermentation compared to the control (Figures 3 and 4). In this case, the meads produced without nitrogen supplementation (control) were not consistent with the Brazilian legislation, Brasil (2012), in relation to the ethanol content, which must be between 4 and $14 \%(\mathrm{v} / \mathrm{v})$ at $20^{\circ} \mathrm{C}$. Thus, the production of this beverage is impracticable without supplementation and that yeast depends on nitrogen for metabolic efficiency.

The increased nitrogen amount available for the yeast increases the use of sugars for conversion into ethanol, Li et al. (2017). S. cerevisiae in musts lacking nitrogen can originate half of the amount of proteins compared to those in musts with sufficient nitrogen, Varela et al. (2004). This may lead to lower capacity of sugar uptake - which probably occurred in the control must - causing deficiencies in the production of cellular compounds, turning the cell more susceptible to stress conditions, like high osmolarity medium. Also, there may be changes in cellular membrane integrity in the presence of high ethanol and low FAN concentrations Schulze et al. (1996).

One of the ways in which yeast cells respond to growth environment changes is through modifications in gene expression profile, which affects the production of the proteins involved in different metabolic functions, including energy generation, carbohydrate metabolism, oxireductase activity, oxidative phosphorylation, transport activity and oxidative stress, Causton et al. (2001); Gasch et al. (2000); Mendes-Ferreira et al. (2007). The availability of nitrogen during fermentation helps maintaining the cell glycolytic capacity, and, consequently, sugar conversion into ethanol. Under conditions of limited 
nitrogen, the expression of enzymes such as hexokinase and phosphofructokinase is reduced, leading to lower glycolytic rates. Albers et al. (2007)

The DNS method applied for reduced sugar quantification has limitations due to the reactivity of the major reagent with color compounds in honey, Vasconcelos et al. (2013). Besides that, DNS can be applied to monitor sugar consumption during fermentation, especially considering that this was a comparative experiment and due to the high proportion between sugars and those colorants. To measure more precisely sugars during mead fermentation, HPLC could be applied, mainly focusing in glucose and fructose decrease.

Honey is composed mostly by fructose, glucose, sucrose and until 25 other oligosaccharides, including maltose, isomaltose and trehalose, which can be used by S. cerevisiae, Bogdanov et al. (2008). Total sugar consumption, but not reducing sugars, was higher in musts supplemented with DAP compared to those with AS (Table 1). This could indicate that DAP supplementation may have enabled yeast to consume specific sugars that would not be consumed under conditions similar of those of the other treatments, due to greater nutrient availability. This could also explain the higher conversion of sugars to ethanol by yeasts in the musts supplemented with DAP at the greatest nitrogen concentration $\left(1.0 \mathrm{~g} \cdot \mathrm{L}^{-1}\right)$, while musts supplemented with AS reached saturation from $0.7 \mathrm{~g} \cdot \mathrm{L}^{-1}$ (Figure 4 ).

The higher conversion of sugars to ethanol by yeasts in the presence of DAP can also be related to the different buffer capacities of these supplements and higher phosphate availability in the fermentative medium supplemented with DAP, Wu et al. (2004). Yeasts acidify the growth medium through the combination of ion absorption, proton secretion during nutrient transport, production of organic acids and $\mathrm{CO}_{2}$ secretion, Walker (1998). Phosphate and sulfate ions - - present in DAP and AS, respectively - act in the medium as different buffer agents together with ammonia groupings. Moreover, the presence of phosphate is related to different cellular functions. It enters the cell by means of low affinity transporters located on the membrane, Ljungdahl \& Daignan-Fornier (2012). This directly affects the energetic balance - ADP/ATP - in the cell and, consequently, sugar metabolism, through glycolytic pathway, which will lead to ethanol production. In other words, a greater amount of inorganic phosphate in the supplemented musts with DAP may have increased ethanol concentration by means of this route.

Thus, using DAP at 1.0 g.L. $\mathrm{L}^{-1}$ in honey musts is recommended for higher ethanol conversion during mead production [higher $\left.\mathrm{Y}_{(\mathrm{P} / \mathrm{S})}(\mathrm{p}<0.05) 0.259 \pm 0.022\right]$ under similar conditions to those carried out in this study.

\section{Conclusion}

The study on the supplementation of honey musts is fundamental for the optimization of the process of mead production, considering the need for using nitrogen supplements, such as DAP and AS, in order to supply FAN deficiency in honey for fermentation by yeasts. No previous studies focused on the effects of supplementation of honey musts with inorganic nitrogen sources alone and the determination of the ideal concentration for ethanol conversion. Addicting DAP and AS to the honey musts led to a higher consumption of sugars by the yeast and generated meads with higher alcohol content. Using DAP at 1.0 g. $\mathrm{L}^{-1}$ has led to higher ethanol conversion by the yeast, while the addition of AS at amounts higher than $0.7 \mathrm{~g} . \mathrm{L}^{-1}$ did not differentiate the final beverage. This may be related mainly to the use of different sugars by yeast in the presence of DAP caused by the extra phosphate provided by this supplement.

\section{References}

Abernathy, D. G., Spedding, G., \& Starcher, B. (2009). Analysis of protein and total usable nitrogen in beer and wine using a microwell ninhydrin assay. Journal of the Institute of Brewing, 115(2), 122-127. http://dx.doi.org/10.1002/j.2050-0416.2009.tb00356.x.

Albers, E., Larsson, C., Andlid, T., Walsh, M. C., \& Gustafsson, L. (2007). Effect of nutrient starvation on the cellular composition and metabolic capacity of Saccharomyces cerevisiae. Applied and Environmental Microbiology, 73(15), 4839-4848. http://dx.doi. org/10.1128/AEM.00425-07. PMid:17545328.

Albers, E., Larsson, C., Lidén, G., Niklasson, C., \& Gustafsson, L. (1996). Influence of the nitrogen source on Saccharomyces cerevisiae anaerobic growth and product formation. Applied and Environmental Microbiology, 62(9), 3187-3195. http://dx.doi. org/10.1128/AEM.62.9.3187-3195.1996. PMid:8795209.

Aquarone, E., Lima, U. A., \& Borzani, W. (1983). Alimentos e bebidas produzidos porfermentação (p. 5). São Paulo: Editora Edgard Blücher.

Barbosa, C., Mendes-Faia, A., \& Mendes-Ferreira, A. (2012). The nitrogen source impacts major volatile compounds released by Saccharomyces cerevisiae during alcoholic fermentation. International Journal of Food Microbiology, 160(2), 87-93. http://dx.doi.org/10.1016/j. ijfoodmicro.2012.10.003. PMid:23177046.

Bely, M., Salmon, J. M., \& Barre, P. (1994). Assimilable nitrogen addition and hexose transport system activity during enological fermentation. Journal of the Institute of Brewing, 100(4), 279-282. http://dx.doi. org/10.1002/j.2050-0416.1994.tb00824.x.

Bogdanov, S., Jurendic, T., Sieber, R., \& Gallmann, P. (2008). Honey for nutrition and health: A review. Journal of the American College of Nutrition, 27(6), 677-689. http://dx.doi.org/10.1080/07315724.2 008.10719745. PMid:19155427.

Brasil, Ministério da Agricultura, Pecuária e Abastecimento. (2012). Instrução Normativa $n^{\circ} 34$, de 29 de novembro de 2012. Diário Oficial [da] República Federativa do Brasil, 53(9), 1689-1699. http:// dx.doi.org/10.1017/CBO9781107415324.004.

Causton, H. C., Ren, B., Koh, S. S., Harbison, C. T., Kanin, E., Jennings, E. G., Lee, T. I., True, H. L., Lander, E. S., \& Young, R. A. (2001). Remodeling of Yeast Genome Expression in Response to Environmental Changes. Molecular Biology of the Cell, 12(2), 323-337. http://dx.doi. org/10.1091/mbc.12.2.323. PMid:11179418.

Childs, B. C., Bohlscheid, J. C., \& Edwards, C. G. (2015). Impact of available nitrogen and sugar concentration in musts on alcoholic fermentation and subsequent wine spoilage by Brettanomyces bruxellensis. Food Microbiology, 46, 604-609. http://dx.doi. org/10.1016/j.fm.2014.10.006. PMid:25475334.

Claro, F. B., Rijsbrack, K., \& Soares, E. V. (2007). Flocculation onset in Saccharomyces cerevisiae: Effect of ethanol, heat and osmotic stress. Journal of Applied Microbiology, 102(3), 693-700. http://dx.doi. org/10.1111/j.1365-2672.2006.03130.x. PMid:17309618. 
Gasch, A. P., Spellman, P. T., Kao, C. M., Carmel-Harel, O., Eisen, M. B., Storz, G., Botstein, D., \& Brown, P. O. (2000). Genomic Expression Programs in the Response of Yeast Cells to Environmental Changes. Molecular Biology of the Cell, 11(12), 4241-4257. http://dx.doi. org/10.1091/mbc.11.12.4241. PMid:11102521.

Jin, Y., \& Speers, R. A. (2000). Effect of Environmental Conditions on the Flocculation of Saccharomyces cerevisiae. Journal of the American Society of Brewing Chemists, 58(3), 108-116. http://dx.doi. org/10.1094/ASBCJ-58-0108.

Kelkar, S., \& Dolan, K. (2012). Modeling the effects of initial nitrogen content and temperature on fermentation kinetics of hard cider. Journal of Food Engineering, 109(3), 588-596. http://dx.doi.org/10.1016/j. jfoodeng.2011.10.020.

Komatsu, S. S., Marchini, L. C., \& Moreti, A. C. D. C. C. (2002). Análises físico-químicas de amostras de méis de flores silvestres, de eucalipto e de laranjeira, produzidos por Apis mellifera L., 1758 (Hymenoptera, apidae) no Estado de São Paulo. 2. Conteúdo de açúcares e de proteína. Food Science and Technology, 22(2), 143-146. http://dx.doi.org/10.1590/S0101-20612002000200007.

L'Organisation Internationale de la Vigne et du Vin - L'OIV. (2015). Méthodes d'analyse: Analyses physiques. In L'Organisation Internationale de la Vigne et du Vin - L'OIV. Recueil des méthodes internationales d'analyse des vins et des moûts (2nd ed.). Paris, France: L'OIV.

Li, Z., Wang, D., \& Shi, Y. C. (2017). Effects of nitrogen source on ethanol production in very high gravity fermentation of corn starch. Journal of the Taiwan Institute of Chemical Engineers, 70, 229-235. http://dx.doi.org/10.1016/j.jtice.2016.10.055.

Ljungdahl, P. O., \& Daignan-Fornier, B. (2012). Regulation of amino acid, nucleotide, and phosphate metabolism in Saccharomyces cerevisiae. Genetics, 190(3), 885-929. http://dx.doi.org/10.1534/ genetics.111.133306. PMid:22419079.

Mamlouk, D., \& Gullo, M. (2013). Acetic acid bacteria: physiology and carbon sources oxidation. Indian Journal of Microbiology, 53(4), 377384. http://dx.doi.org/10.1007/s12088-013-0414-z. PMid:24426139.

Mendes-Ferreira, A., Barbosa, C., Falco, V., Leão, C., \& Mendes-Faia, A. (2009). The production of hydrogen sulphide and other aroma compounds by wine strains of Saccharomyces cerevisiae in synthetic media with different nitrogen concentrations. Journal of Industrial Microbiology \& Biotechnology, 36(4), 571-583. http://dx.doi. org/10.1007/s10295-009-0527-x. PMid:19190948.

Mendes-Ferreira, A., Cosme, F., Barbosa, C., Falco, V., Inês, A., \& Mendes-Faia, A. (2010). Optimization of honey-must preparation and alcoholic fermentation by Saccharomyces cerevisiae for mead production. International Journal of Food Microbiology, 144(1), 193-198. http://dx.doi.org/10.1016/j.ijfoodmicro.2010.09.016. PMid:20937538.

Mendes-Ferreira, A., Del Olmo, M., García-Martínez, J., JiménezMartí, E., Mendes-Faia, A., Pérez-Ortín, J. E., \& Leão, C. (2007). Transcriptional response of Saccharomyces cerevisiae to different nitrogen concentrations during alcoholic fermentation. Applied and Environmental Microbiology, 73(9), 3049-3060. http://dx.doi. org/10.1128/AEM.02754-06. PMid:17337556.

Mendes-Ferreira, A., Mendes-Faia, A., \& Leão, C. (2004). Growth and fermentation patterns of Saccharomyces cerevisiae under different ammonium concentrations and its implications in winemaking industry. Journal of Applied Microbiology, 97(3), 540-545. http:// dx.doi.org/10.1111/j.1365-2672.2004.02331.x. PMid:15281934.

Pierce, J. S. (1970). Institute of brewing: analysis committee measurement of yeast viability. Journal of the Institute of Brewing, 76(5), 442-443. http://dx.doi.org/10.1002/j.2050-0416.1970.tb03325.x.
Ribereau-Gayon, P., Dubourdieu, D., Doneche, B., \& Lonvaud, A. (2006). Handbook of enology: The microbiology of wine and vinifications (2nd ed., Vol. 1). Hoboken, Nova Jersey: John Wiley \& Sons, Ltd. https:// doi.org/10.1002/0470010363.

Schulze, U., Lidén, G., Nielsen, J., \& Villadsen, J. (1996). Physiological effects of nitrogen starvation in an anaerobic batch culture of Saccharomyces cerevisiae. Microbiology, 142(1), 2299-2310. https:// doi.org/10.1099/13500872-142-8-2299.

Silva, F. A. S. S., \& Azevedo, C. A. V. A. (2016). The Assistat Software Version 7.7 and its use in the analysis of experimental data. African Journal of Agricultural Research, 11(39), 3733-3740. http://dx.doi. org/10.5897/AJAR2016.11522.

Silva, M. S. (2016). Desenvolvimento de fermento para produção de hidromel (Tese de doutorado). Programa de Pós-graduação em Ciência e Tecnologia de Alimentos, Viçosa.

Sumner, J. B. (1921). Dinitrosalicylic acid: a reagent for the estimation of sugar in normal and diabetic urine. The Journal of Biological Chemistry, 47, 5-9.

Soares, E. V. (2011). Flocculation in Saccharomyces cerevisiae: A review. Journal of Applied Microbiology, 110(1), 1-18. http://dx.doi. org/10.1111/j.1365-2672.2010.04897.x. PMid:21114594.

Soares, E. V., Vroman, A., Mortier, J., Rijsbrack, K., \& Mota, M. (2004). Carbohydrate carbon sources induce loss of flocculation of an ale-brewing yeast strain. Journal of Applied Microbiology, 96(5), 1117-1123. http://dx.doi.org/10.1111/j.1365-2672.2004.02240.x. PMid:15078529.

Tesnière, C., Brice, C., \& Blondin, B. (2015). Responses of Saccharomyces cerevisiae to nitrogen starvation in wine alcoholic fermentation. Applied Microbiology and Biotechnology, 99(17), 7025-7034. http:// dx.doi.org/10.1007/s00253-015-6810-z. PMid:26201494.

Touhami, A., Hoffmann, B., Vasella, A., Denis, F. A., \& Dufrêne, Y. F. (2003). Aggregation of yeast cells: Direct measurement of discrete lectin-carbohydrate interactions. Microbiology, 149(10), 2873-2878. http://dx.doi.org/10.1099/mic.0.26431-0. PMid:14523119.

Varela, C., Pizarro, F., \& Agosin, E. (2004). Biomass content governs fermentation rate in nitrogen-deficient wine musts. Biomass Content Governs Fermentation Rate in Nitrogen-Deficient Wine Musts, 70(6), 3392-3400. http://dx.doi.org/10.1128/AEM.70.6.3392-3400.2004. PMid:15184136.

Vasconcelos, N. M., Pinto, G. A. S., \& Aragão, F. A. S. (2013). Determinação de Açúcares Redutores pelo Ácido 3,5-Dinitrosalicílico (Boletim de Pesquisa, No. 9, pp. 1-59). Fortaleza: Embrapa Agroindústria Tropical.

Vendramini, C., Beltran, G., Nadai, C., Giacomini, A., Mas, A., \& Corich, $\mathrm{V}$. (2017). The role of nitrogen uptake on the competition ability of three vineyard Saccharomyces cerevisiae strains. International Journal of Food Microbiology, 258(June), 1-11. http://dx.doi.org/10.1016/j. ijfoodmicro.2017.07.006. PMid:28735228.

Vidal, E. E., De Billerbeck, G. M., Simões, D. A., Schuler, A., François, J. M., \& De Morais, M. A. Jr (2013). Influence of nitrogen supply on the production of higher alcohols/esters and expression of flavour-related genes in cachaça fermentation. Food Chemistry, 138(1), 701-708. http://dx.doi.org/10.1016/j.foodchem.2012.10.147. PMid:23265543.

Walker, G. M. (1998). Wiley: Yeast physiology and biotechnology. England: Wiley.

Wu, J., Zhang, N., Hayes, A., Panoutsopoulou, K., \& Oliver, S. G. (2004). Global analysis of nutrient control of gene expression in Saccharomyces cerevisiae during growth and starvation. Proceedings of the National Academy of Sciences of the United States of America, 101(9), 3148-3153. http://dx.doi.org/10.1073/pnas.0308321100. PMid:14973188. 